\title{
STRUCTURAL AND FUNCTIONAL ORGANIZATION OF PERSONALITY REFLEXIVE COMPETENCE IN MODERN PSYCHOLOGY
}

\author{
Serhii Illiuschenko \\ Adjunct at the Department of Social Sciences, National Defense University of Ukraine \\ named after Ivan Cherniakhovskyi, Ukraine \\ e-mail: sergey.illushenko@gmail.com,orcid.org/0000-0002-5963-8020
}

\section{Summary}

This article is a theoretical study of the "reflexive competence" concept and other related notions in the context of psychological science. Reflexive competence is viewed as an important component of professional competence and a separate formation of mind that determines the resultant aspect of reflexive activity.

The study is based on the analysis of non-fiction works on the subject matter written by Ukrainian and foreign authors. It shows the diversity of approaches to definition of the "reflexive competence" concept and to detailing of the aspects of its structure.

The article describes the types of reflection and examines every single component of reflexive competence, including cooperative, communicative, personal and intellectual reflection. It also looks at the models of reflexive competence and its individual structural components, such as informational, instrumental, judgmental and motivational, and behavioral.

The article explains why we need to study reflexive competence as a complex formation - a meta-concept, a personal meta-competence that integrates knowledge, abilities and skills acquired in the course of personal growth and associated with the realization of why people do what they do, with identification and resolution of problems that arise in the course of our primary activity, and with the setting of goals and prioritization of personal growth areas.

The work also proves the importance of reflexive competence as a professional growth driver for the officers of Ukraine armed forces and an aspect that facilitates development of other kinds of personality competence.

Keywords: competence, reflexive competence, cooperative reflection, communicative reflection, personal self-reflection, intellectual self-reflection, social reflection, individual self-reflection.

DOI: https://doi.org/10.23856/4620

\section{Introduction}

The attitude to the chosen profession, the ability to look at it from the sidelines and to see ourselves inside of the profession play a big role in our personal development as professionals. According to the analysis of some treatises, the scientists investigating into the matter of building the competence of a future specialist refer to the multifaceted concept of "reflexive competence". The main reason of that is because the self-cognition and cognizing of others are based on the reflexive processes. This is why reflexive competence is seen as a tool of social/perceptive and autopsychological competence. The importance of mastering one's reflexive competence in into professional activity is indisputable, since it facilitates adequate self-realization of a specialist through the cognition of his or her own abilities and qualities and their resulting development. Reflexive competence plays a paramount role 
in the rethinking of a specialist's personal and professional experience, which facilitates development of new professional models and standards that inspire development. Reflexive competence is an important professional growth driver for the personality. It also defines personal growth as the most effective type of development and establishment of professional activity. Reflexive competence is precisely what promotes the development of other kinds of personality competence by activating the knowledge system and the established reflection mechanisms.

Many Ukrainian and foreign scientists, including G. Alekseyev, A. Metayeva, O. Polishchuck, A. Savchenko, I. Semenov, S. Stepanov, G. Shchedrovitsky and others, devoted their time to studying the problem of reflexive competence. Their works describe the essence of reflexive competence, reflection and reflexivity, as well as the structural and functional organization of reflexive competence.

This article aims to investigate the psychological aspects of the "reflexive competence" concept and describe the structure of reflexive competence.

Review and analysis of existing scientific works, synthesis and introspection were used in the article as research methods.

\section{Current trends of studying the reflexive competence concept}

The current trends of evolution are growing exponential when innovative technologies start to prevail over the traditional ones and, as a consequence, the human development paradigm changes. Today's world is characterized by continuous growth of information volumes, increasing importance of personality, intellectualization of its activity, as well as rapid changes in the engineering and technology developments worldwide. "More than 500 old professions disappear and new professions emerge in the same quantity in the global economy every year. In the past, you could acquire professional knowledge as a student and worked successfully and efficiently for 20-25 years after that. Nowadays, the maximum period of your education effectiveness is around 5 to 7 years, and half that much in the sectors that drive technological progress." (Borovik et al., 2001). As a result, professionals are urged to acquire profound knowledge, show personal development skills and ability to learn and upgrade their skills continuously.

Today, psychological science has everything it needs to establish and rapidly develop the competence-based approach to studying of personality. This accelerated the shaping a perspective of competence as an important formation of personality that enables effective self-fulfillment of a person in certain formats of activity.

Most researchers considered the reflexive competence concept as an important component of professional competence or professional activity (Voitik, 2010: 51-56). However, few of them studied the reflexive competence as a separate formation of mind that determines the resultant aspect of reflexive activity (Savchenko, 2017).

One of first definitions of reflexive competence concept was presented by O. Polishchuck. The scientist defined the concept as "a professional feature of personality that enables one to carry out the reflection processes in the most effective and adequate manner, helps achieve one's capacity for reflection, promotes creativity in professional activity and facilitates maximum efficiency and productivity of labor" (Polishchuck, 1995). In the researcher's opinion, this concept must take its place among the existing notions, such as "reflection", "reflexivity", "reflexive readiness", "reflexive culture", etc. The provided definition is more universal, which is why is used by the majority of scholars. 
A similar definition of the concept of reflexive competence was provided by V. Raskalinos, defining it as the awareness of a specialist regarding "the processes of actualization of personality, the realization of reflexive abilities in understanding and overcoming thinking stereotypes and the formation of new innovative content" (Raskalinos, 2011).

K. Nor and Y. Babayan offer their perspective on the notion of reflexive competence as an integrative personal quality that characterizes the degree of mastering all the aspects of reflexive competences; this perspective suggests a characterization of reflexive activity through knowledge, practice, professional skill and personal experience (Babayan et al., 2013).

\section{The reflexive competence structure}

S. Stepanov and I. Semenov made a substantial contribution to development of the "reflexive competence" concept in the leaders' professional growth system. They also defined the reflexive competence concept as "a complex formation that includes knowledge about rolebased structure and positional organization of the collective interaction (cooperative reflection), perception of inner world of others and reasons behind their actions (communicative reflection); acts, behavior and images of "ego" as an individuality (personal self-reflection); as well as knowledge about a subject methods of interaction with it (intellectual self-reflection)" (Stepanov et al., 1996: 27).

From the above structure we can see that cooperative and communicative aspects of the reflexive competence concept are the collective forms of activity and relate to social sphere. They constitute social reflection. The personal and intellectual self-reflection both appear as individual forms of thinking and consciousness and are grouped into the category of individual self-reflection.

Let us take a look at every individual component of reflexive competence. The first component is the so-called cooperative aspect of reflection, in other words, reflection realized through cooperative activity. Its object is knowledge about the role-based structure and positional organization of the collective interaction. A. Anisimov, M. Alekseyev, V. Rubtsov, A. Tukov and G. Shchedrovitsky devoted their works the problem of this kind of reflection. They interpret reflection as a "step-out" of a subject to view its activity from the outside (Alekseyev et al., 1991). The cooperative aspect of reflection enables coordination of professional positions and joint action of the subjects in collective activity. In this case, the results of reflection are the most important thing, not procedural mechanisms or individual differences in their expression.

G. Andreyeva, A. Bodalev, N. Gutkina, K. Danilin, O. Smirnova and A. Sopikov devoted their works the problem of communicative reflection. Its object is the perception of inner world of others and the reasons behind their actions. The works consider reflection as a significant component of communication and interpersonal perception (Danilin, 1981). This type of reflection may bring a new understanding of how a person is perceived by his or her communication partners and lead to changes in the communicative style.

Intellectual self-reflection explorers, including M. Alekseyev, L. Bertsfay, L. Gurova, A. Zack, I. Semenov and S. Stepanov, believe that intellectual self-reflection permits to describe the perception of psychological mechanisms of theoretical thinking (Bertsfay, 1966). The authors identify the following types of intellectual self-reflection: extensive, intensive and constructive. Extensive self-reflection determines and controls the progression of a problem in a way that is clear to the subject and is realized through beliefs. Intensive self-reflection, in turn, expresses questions and judgments, which means that it is directly related to the subject's 
attitude to the object of self-reflection as something doubtful and even confusing. Constructive self-reflection simulates a general strategy of reflexive movement using such functional elements as assumption and affirmation.

N. Gutkina, E. Novikova, I. Semenova, S. Stepanov, V. Zaretsky and others devoted their works the problem of personal self-reflection. The scientists indicated that intellectual neologisms are traditionally investigated in the personality structure should be explored hand in hand with the personal neologisms. They found a change in the existence of the initial reproductive personal position of an actor with regard to the future search for solution against the new productive personal position, which in fact is the neologism that emerges when we stimulate the development of personal self-reflection.

\section{Reflexive competence concept as a meta-competence of personality}

A. Savchenko defines the reflexive competence concept as an important personal meta-competence that integrates the knowledge, abilities and skills acquired in the course of personal growth and associated with the realization of why people do what they do, with identification and resolution of problems that arise in the course of our primary activity, and with the setting of goals and prioritization of personal growth areas. It is reflexive competence that facilitates the development of other types of personality competence through activation of the knowledge system and existing mechanisms of reflection (Savchenko, 2017).

Y. Zhukov, L. Petrovskaya and A. Solovyova have the same point of view and notice that "a practitioner becomes a real professional by putting their own practice to self-reflection or at least taking some effort to interpret it" (Zhukov, 1999: 13).

$\mathrm{V}$. Metayeva, referring to a number of previous studies based on the acmeological approach (A. Dergach, E. Zeyer, I. Zimnyaya, I. Semenov, A. Khutorskoy), also defines reflexive competence as a meta-competence that helps one achieve the best results in their activity (Zhukov, 1999: 13).

There is a widespread model of reflexive competence that includes three components: cognitive (knowledge about self-reflection, about the tools of reflexive activity, and general requirements for professional activity); operational (skills of analyzing one's own thoughts and actions, self-control and personal growth; reflexive methods that make professional activity more effective at its different stages); personal (ability to plan and forecast one's capabilities; readiness for creative work and personal growth; empathy).

However, the model of reflexive competence offered by A. Savchenko is more suited to our views. This model includes three levels of reflexive competence functioning: cognitive (representation and control of one's mental activity), meta-cognitive (adjustment of mental activity self- regulation of reflexive activity), and personal (generation and consolidation of new mental formations through rethinking of current situations, re-interpretation of experience and explanation of the "me - concept"), and it combines four components. The structural components of reflexive competence are: 1) informational component that enables adequate understanding of the problem through generation of adequate representations of the problem, models of the problem solving process, and understanding of ourselves as a subject of reflexive activity (knowledge about reflection and reflexive activity forms, meta-cognitive knowledge of the subject regarding his or her own reflexive activity, model of "self-reflecting me"); 2) instrumental component that enables high productivity of reflexive forms of activity (the system of cognitive, meta-cognitive and personal reflexive skills); 3) judgmental and motivational component that controls performance of actions (system of criteria used for evaluating 
the subject's reflexive activity, predicting of his or her own activity, personal growth mission); 4) behavioral component that allows us to act in situations of uncertainty (reflexive strategies of problem-solving, reflectivity as a cognitive and style property, reflexive style of solving of internal contradictions in conflict situations).

\section{Conclusions}

Consequently, we can make the following conclusion: despite certain differences in the views on the reflexive competence structure, all the authors agree that the reflexive competence concept is a complex formation. This is because the subject can put to reflection:

- his or her actions, behavior and "me-" images of their individuality;

- perception of the inner world of other and the reasons behind their actions;

- knowledge about an object and ways of interaction with it;

- knowledge about role-based structure and positional organization of collective interaction.

Comparing reflexive competence and other types of competencies that are studied in psychology, we see that the reflexive competence is a meta-concept, a meta-competence that uses the reflection mechanism to ensure timely adjustment and adequate development of other competencies.

Reflexive competence is essentially the awareness of one's mission, its fulfillment and recognition of the social value the work product by means of comprehensive and multifaceted analysis. In this case, reflexive competence finds expression in the form of analysis of one's activity in terms of both the content and the method of such activity.

Reflexive competence is an important professional growth driver for the personality. It defines personal growth as the most effective type of development and establishment of professional activity. Reflexive competence plays a paramount role in the rethinking of a specialist's personal and professional experience, which facilitates development of new professional models and standards that inspire development.

\section{References}

Alekseev, N.G., Zareckii V.K., Ladenko, I.S., \& Semenov I.N. (1991). Metodologiya refleksii konceptualnih shem deyatelnosti poiska i prinyatiya resheniya [Methodology of reflection of conceptual schemes of activity search and decision-making]. Novosibirsk: Publishing house of the Novosibirsk State University. [in Russian].

Babayan, Yu.O., \& Nor, K.F. (2013). Struktura refleksyvnoi kompetentnosti vykladacha vyshchoi shkoly [Structure of reflexive competence of A Higher School teacher]. Nikolaev: Nikolaev National University named after V. A. Sukhomlinsky. [in Ukrainian].

Bercfai, L.V. (1966). Formirovanie umeniya v situacii resheniya konkretno prakticheskih $i$ uchebnih zadach [Formation of skills in the situation of solving specific practical and educational tasks]. Moscow: Scientific Research. institute of psychology. [in Russian].

Borovik, V.S., Ermakova, E.E., \& Pohvoschev, V.A. (2001). Zanyatost naseleniya [Employment of the population]. Rostov-on-Don: Phoenix. [in Russian].

Voitik, I.M. (2010). Intellektualnii tip refleksii v professionalnom obrazovanii [Intellectual type of reflection in professional education]. Novosibirsk: Philosophy of Education. [in Russian]. Danilin, K.E. (1981). Formirovanie vnutrigruppovih ustanovok i refleksivnoi strukturi gruppi / Mejlichnostnoe vospriyatie v gruppe [Formation of intragroup attitudes and reflexive structure 
of the group / Interpersonal perception in the group]. Moscow: Moscow University Press. [in Russian].

Jukov, Yu.M., Petrovskaya, L.A., \& Soloveva, O.V. (1999). Vvedenie v prakticheskuyu socialnuyu psihologiyu [Introduction to practical social psychology]. Moscow: Meaning. [in Russian].

Metaeva, V.A. (2006). Refleksiya kak metakompetentnost [Reflection as a meta-competence]. Moscow: Psychology of Training. [in Russian].

Polischuk, O.A. (1995). Razvitie refleksivnoi kompetentnosti kadrov gosudarstvennoi slujbi [Development of reflexive competence of civil service personnel]. Moscow: Russian Academy of Public Administration. [in Russian].

Raskalinos, V.M. (2011). Refleksyvna kompetentnist yak skladova profesiinoi kharakterystyky maibutnoho [Reflexive competence as a component of the professional characteristics of the future]. Uman: Uman State Pedagogical University named after Pavel Tychina. [in Ukrainian]. Savchenko, O.V. (2017) Psykholohiia refleksyvnoi kompetentnosti osobystosti [Psychology of reflexive personality competence]. Kyiv: Taras Shevchenko National University of Kyiv. [in Ukrainian].

Stepanov, S.Yu., Polischuk, O.A., \& Semenov, I.N. (1996). Razvitie refleksivnoi kompetentnosti kadrov upravleniya: metodicheskie rekomendacii. [Development of reflexive competence of management personnel: methodological recommendations]. Moscow: Russian Academy of Public Administration. [in Russian]. 